\title{
Anna Kostecka-Sadowa \\ Rzeczownikowe zapożyczenia wschodniosłowiańskie w gwarach polskich \\ Instytut Języka Polskiego PAN, Kraków 2015, ss. 488
}

Językowe kontakty i wzajemne oddziaływania języka polskiego i języków wschodnio-słowiańskich cieszą się zainteresowaniem językoznawców, zwłaszcza polonistów i slawistów, od dawna. Badania nad tym zagadnieniem mają nie tylko wieloletnią tradycję, ale też bogaty i zróżnicowany dorobek wypracowany $\mathrm{z}$ uwzględnieniem różnych uwarunkowań merytorycznych, kontekstów historyczno-geograficznych i perspektyw metodologicznych. Badacze brali pod uwagę wpływy wschodniosłowiańskie obecne $\mathrm{w}$ różnych odmianach języka polskiego, ale najczęstszym przedmiotem ich zainteresowania była polszczyzna ogólna, w tym język artystyczny, oraz rozmaicie traktowana odmiana kresowa polszczyzny, wreszcie odmiany regionalne i ludowe, funkcjonujące na wschodniej peryferii Polski w warunkach językowego pogranicza polsko-ruskiego. Inne warianty polszczyzny, na przykład gwary innych regionów, budziły pod tym względem znacznie mniejsze zainteresowanie. Co więcej, zapożyczenia wschodniosłowiańskie $\mathrm{w}$ żadnej $\mathrm{z}$ tych płaszczyzn językowych nie doczekały się wszechstronnego syntetycznego ujęcia. Dotyczy to także ogółu polskich gwar ludowych. Na ten fakt zwraca uwagę sama autorka. Uzasadniając wybór przedmiotu i określając charakter opracowania, podkreśla, że do tej pory nie powstało wyczerpujące całościowe opracowanie problematyki zapożyczeń wschodniosłowiańskich w gwarach polskich (s. 13). Zakłada jednocześnie, że to właśnie jej opracowanie tę dotkliwą lukę powinno zapełnić. Już po bardzo wstępnym oglądzie opracowania, przyznając zarazem rację recenzentowi wydawniczemu, trzeba jednoznacznie stwierdzić, że w żadnym razie nie jest to deklaracja bez pokrycia. 
Na to imponujące nie tylko pod względem obszerności (niemal pół tysiąca stron w formacie B-5), ale i bogactwa zagadnień, dzieło składają się trzy zasadnicze części. Pierwszą rozpoczyna lapidarne, ale treściwe Słowo wstępne, opatrzone wiele mówiącym podtytułem uwagi na temat istoty badania gwar (s. 11-12). Istota tych uwag sprowadza się do merytorycznego uzasadnienia znaczenia badań gwar ludowych nie tylko dla historii języka, ale też wiedzy o przeszłości narodowej kultury. Właściwą początkową część opracowania tworzy rozdział Wprowadzenie (s. 13-56). W podrozdziale zatytułowanym Informacje ogólne i metodologiczne otrzymujemy wymagane $\mathrm{w}$ monografiach naukowych określenie ogólnych i szczegółowych celów pracy, za które Kostecka-Sadowa uznaje przedstawienie ogółu zapożyczeń wschodniosłowiańskich funkcjonujących w gwarach polskich, ze szczególnym uwzględnieniem ich zasięgów geograficznych, stopnia zaadaptowania $\mathrm{w}$ gwarach pod względem formalnym i semantycznym, mechanizmów ich funkcjonowania w gwarach. Swoje zainteresowanie autorka ogranicza do zapożyczeń rzeczownikowych (łącznie 700 jednostek), w tym różnych postaci słowotwórczych wyrazu podstawowego. Uwzględnia także - co może budzić wątpliwości - zleksykalizowane kalki wyrazowe, pomija natomiast - i słusznie - wtręty, zwane inaczej cytatami. Dobór materiału ma charakter dyferencyjny, dlatego autorka z założenia zajmuje się wyłącznie słownictwem gwarowym, czyli takim, które jest nieobecne w polszczyźnie ogólnej lub występuje w niej w odmiennych znaczeniach. Ramy chronologiczne materiału gwarowego stanowią: koniec XIX wieku i czasy współczesne (s. 27).

Zapożyczenia i ich rodzaje (formalnosemantyczne, kalki strukturalne i semantyczne) są definiowane i wyłaniane tradycyjnie (s. 31-32). Autorka w zgodzie z Bogdanem Walczakiem przyjmuje postawę leksykalistyczną, uznając za źródło pożyczki ostatnie ogniwo w łańcuchu przejęcia (Walczak 1980: 176), omawia także sposoby przenikania wschodnich slawizmów do języka polskiego i mechanizmy adaptacyjne.

W tej części opracowania Kostecka-Sadowa zwraca uwagę na okoliczności, które utrudniają interpretację materiału. Za najważniejsze uznaje zgodność formalną i semantyczną wyrazów rosyjskich, białoruskich i ukraińskich, która sprawia, że precyzyjne określenie źródła pożyczki jest niełatwe. Sprawę komplikuje też to, że języki ruskie, zwłaszcza w odniesieniu do starszych pokładów zapożyczeń, stanowią bardzo często medium w przejęciach z języków orientalnych, np. takich wyrazów, jak: arbuz, bezmian, bisurman, buhaj, chabor, czaban, kaczan, kaleta, meszty, telega. 
Z kolei bliskie pokrewieństwo języków wschodniosłowiańskich i polszczyzny, a w efekcie podobieństwo strukturalne, często uniemożliwia wskazanie, które wyrazy są rzeczywiście zapożyczeniami, a które innowacjami leksykalnymi czy utrzymującymi się $\mathrm{w}$ gwarze archaizmami (por. Smułkowa 1984: 67-73). Nie zawsze da się jednoznacznie wskazać kierunek przejęcia (polonizm $w$ językach ruskich czy rutenizm w polszczyźnie), problemów nastręcza także chronologia zapożyczeń oraz terminologia.

Sporo uwagi poświęca autorka dorobkowi językoznawstwa w zakresie badań nad zapożyczeniami wschodniosłowiańskimi w języku polskim, poczynając od prekursorskich opracowań z końca XIX wieku oraz nowatorskiej pracy Kazimierza Nitscha (1913), kończąc na opracowaniach z początku XXI wieku. Przedmiotem jej uwagi są głównie prace szczegółowe, dotyczące nie tylko gwar ludowych, ale i polszczyzny ogólnej. Szczególne miejsce zajmują w tym omówieniu monografie poświęcone językowi autorów, zwłaszcza związanych z kresami wschodnimi, m.in. prace S. Hrabca (1949), W. Doroszewskiego (1934), J. Trypućki $(1955,1957)$, J. Zaleskiego $(1969,1975)$, ale nie brak też odwołań do ujęć syntetycznych, np. Z. Klemensiewicza (1974) czy I. Bajerowej (1964). Zrozumiałe, że w znacznie większym zakresie interesują Kostecką-Sadową opracowania traktujące o wpływach wschodniosłowiańskich $\mathrm{w}$ gwarach, również zainicjowane u schyłku wieku XIX. Warte podkreślenia jest to, że $\mathrm{w}$ tym omówieniu poza pracami szczegółowymi, m.in. J. Kościa (1999), W. Kuraszkiewicza (1932), H. Pelcowej $(1997,2001)$, T. Zdancewicza $(1964,1966)$ bardzo ważne miejsca zajmują atlasy gwarowe, np. Atlas gwar wschodniostowianskich Białostocczyzny (1980-2012) czy Atlas gwar mazowieckich (1971-1990) i wybory tekstów gwarowych, np. z Białostocczyzny (1972).

W zasadniczej części pracy (s. 57-361), czyli w słowniku wschodnich slawizmów, za nadrzędne uznała autorka kryterium semantyczne, materiał zatem został ułożony, za Ryszardem Tokarskim (1975: 275-282), $\mathrm{w}$ formie piętrowo zbudowanych a zorientowanych antropocentrycznie pól znaczeniowych. $\mathrm{W}$ ich ramach obowiązuje układ alfabetyczny. Dwa główne pola to CZLOWIEK i PRZYRODA. W obrębie bardziej skomplikowanego pola CZŁOWIEK mamy subpola: „Człowiek w społeczeństwie, człowiek i jego atrybuty”, a niżej „Nazwy człowieka ze względu na cechy psychiczne i fizyczne", "Nazwy stopni pokrewieństwa i powinowactwa”, ,Nazwy ludzi ze względu na posiadane godności”, „Nazwy części 
ciała" itd. To ujęcie można uznać za nowatorskie w porównaniu z tradycyjnym przedstawianiem materiału leksykalnego, w tym kresowego, jak na przykład w powszechnie znanych pracach Zofii Kurzowej, czy to traktującej o polszczyźnie „wileńskiej” (1993), czy też „lwowskiej” (1983).

Najważniejszymi elementami poszczególnych artykułów hasłowych, o różnej wielkości, poza samymi hasłami i ich odmiankami fonetycznymi, są informacje etymologiczne, z mniej lub bardziej szczegółowym i precyzyjnym określeniem źródła zapożyczenia, bogata dokumentacja źródłowa, określenie zasięgów geograficznych wschodnich slawizmów w gwarach, ustalenia dotyczące przynależności nazw do różnych warstw chronologicznych, omówienie rozwoju semantycznego, a także inne informacje i komentarze. Te ostatnie elementy składowe pojawiają się najczęściej w wypadku wyrazów budzących różnorodne wątpliwości interpretacyjne, zwykle dawnych przejęć, o dużym zasięgu gwarowym i skomplikowanym rozwoju semantycznym, jak: bohater, bojar, hajdamaka, hultaj, kozak i in. W roli podhaseł występują derywaty tworzone od podstawowego wyrazu, np. kozak, kozaczeńko, kozaczka, kozacznica.

Mimo rozlicznych wątpliwości interpretacyjnych Kosteckiej-Sadowej udało się jednak jednoznacznie ustalić źródło, z którego zaczerpnęła polszczyzna większość z 700 wziętych pod uwagę słów. I tak, za niewątpliwe rusycyzmy uznaje autorka wyrazy typu: barachło, bardach, batiuszka, blin, burłak, bołtun, chłam, pałatka, samogon, starowier. Ukrainizmami są według niej, m.in.: bohater, chata, hałaburda, kacap, mołodziec, okorek, połonina, prynuka, sobaka, a białorutenizmami: baleja, bołbotun, boćwina, brodziaga, bruczka, gładysz, kaduszka, kwaszenina, kindziuk. W wielu jednak wypadkach zamierzonego celu nie udało się autorce osiągnąć, głównie ze względu na czynniki wcześniej wspomniane. W takich sytuacjach konkretne zapożyczenia są traktowane jako wschodnie slawizmy, rutenizmy lub pożyczki ruskie. Ma to miejsce na przykład w wypadku takich wyrazów, jak: czeremcha, czerep, durak, hreczka, hultaj, morda, palczatka, ryło, zielepuchy. Jeszcze częściej mamy do czynienia z alternatywną wersją pochodzenia zapożyczenia. Interpretacja typu albo/albo dotyczy m.in. wyrazów: bajstruk, bałabuch, juszka, kołdoba, koczerga, koromysło, niezabudka, pacuk, skowroda, smorodzina, wienik, wi(e)rówka, zagwozdka. Warto podkreślić, że ustalanie źródła zapożyczenia, jego charakteru, a nawet kierunku przejęcia nie ułatwia niejasna etymologia części analizowanego słownictwa, na przykład wyrazów: hajdawery, kałamaszka, kozyrek, kraszanka, kucza, trybuch. 
Ważnym, zwłaszcza dla czytelnika, elementem opracowania są zakończenia kolejnych podrozdziałów, w których autorka syntetycznie podsumowuje dane szczegółowe, dotyczące przede wszystkim etymologii, geografii i rozwoju semantycznego przeanalizowanych form.

Zdumiewa ogromna baza źródłowa zawierająca ponad pół tysiąca pozycji (s. 387-408) oraz ogromna literatura licząca ok. 1200 prac (s. 409-456). Pozytywnej oceny rozmiarów obu wykazów, jak i ich jakości nie może pomniejszać fakt, że kilkadziesiąt opracowań źródłowych jest też ujętych po stronie literatury, a niektórych prac zabrakło, na przykład poświęconych polszczyźnie kresowej, m.in. B. Smolińskiej (1983) czy U. Sokólskiej (1999). Warto jednocześnie podkreślić, że zarówno źródła materiałowe, jak i pozycje bibliograficzne są $\mathrm{w}$ pracy intensywnie wykorzystywane, zwłaszcza przy analizie poszczególnych jednostek leksykalnych. Widać, że doświadczenia w zakresie kwerendy językoznawczej i etnograficznej uzyskane przez autorkę $\mathrm{w}$ pracowni Stownika gwar polskich tu procentują.

W roli źródeł materiału gwarowego występują opracowania tradycyjnie wykorzystywane przez dialektologów i szerzej slawistów. Należą do nich w pierwszej kolejności atlasy gwarowe obejmujące zarówno małe obszary dialektalne, na przykład okolic Włodawy (Czyżewski 1986), jak i duże kompleksy dialektów (Kaszubszczyzna, Mazowsze, Śląsk). Podobnie rzecz się przedstawia $w$ zakresie słowników, mamy tu duże słowniki (np. gwar ostródzkiego, Warmii i Mazur), jak i średnie (warmiński słownik Steffena - 1984) i małych rozmiarów (por. Woźniak 2000: 32), opracowywane przez całe zespoły redakcyjne, jak i przez indywidualnych autorów ${ }^{1}$. Co więcej, materiały słownikowe obejmują ponad 150 lat, $\mathrm{z}$ jednej strony znajdują się $\mathrm{w}$ wykazie słowniczki dziewiętnastowieczne, na przykład Antoniego Wagi z 1860 - por. Nowowiejski 2014) i z przełomu wieków XIX i XX, na przykład augustowski słownik Aleksandra Osipowicza (por. Nowowiejski 2009), jak i z całego wieku XX, a nawet pojedyncze z przełomu XX i XXI wieku.

Ważnym źródłem słownictwa gwarowego są też liczne zbiory tekstów gwarowych, z obszaru właściwie całej Polski i znów obejmujące obszerną przestrzeń czasową. Naturalną częścią tekstów źródłowych i bibliograficznych są monografie językoznawcze czy to traktujące o konkret-

1 Szerzej klasyfikację polskich słowników gwarowych przedstawia Halina Karaś (2011: 32-54). 
nej gwarze (małej lub o większym zasięgu), czy też o konkretnych zjawiskach fonetycznych, fleksyjnych i słowotwórczych, rzutujących na sposób interpretacji materiału leksykalnego, zwłaszcza w zakresie etymologii. Co innego, że niejednokrotnie istotną część takiej monografii stanowią słowniczki gwarowe, jak ma to miejsce w wypadku opisu dialektu malborskiego (Górnowicz 1967, 1973, 1975) czy dialektu Księstwa Łowickiego (Koneczna-Świderska 1929).

O dużej wartości ocenianego opracowania, zwłaszcza wiarygodności etymologicznych analiz i interpretacji, decyduje także wykorzystanie przez autorkę licznych materiałów etnograficznych, z zakresu ludowej kultury materialnej i duchowej. Rzecz jasna, samo takie ogólnikowe sformułowanie nie oddaje istoty i zakresu materiałów. Poza tekstami foklorystycznymi, reprezentującymi różne formy wypowiedzi (proza, poezja, pieśń, szopka) w większej części pierwotnie mówionymi, zwykle łączącymi w sobie walory artystyczne i dydaktyczne (bajki, fraszki, podania i legendy, przypowieści, gawędy, „pogodki”), mamy w omawianym materiale także liczne materiały o innym charakterze, $\mathrm{w}$ tym dotyczące budownictwa wiejskiego i opisu obejścia, różnych pomieszczeń, a nawet wyposażenia domostw (meble i inne sprzęty). Inne prace dotyczą spraw gospodarskich, na przykład uprawy roli i roślin, czy hodowli zwierząt, rybactwa, pasterstwa górskiego i pszczelarstwa. Z zakresu przemysłu i rzemiosła ludowego na wymienienie zasługują garncarstwo, produkcja ceramiki, tkactwo, sitarstwo. Dość liczne opracowania traktują o tradycyjnych strojach i kulinariach. Wykaz opracowań etnograficznych zamykają dzieła, traktujące o wiejskiej obyczajowości, na przykład zabawach, obrzędach weselnych, pogrzebowych, czy związanych z narodzinami dziecka, ludowej medycynie i związanej z tym sferą wierzeń, czyli przesądach, zabobonach i "gusłach".

Do opiniowanego opracowania nie mam większych zastrzeżeń. Pewne wątpliwości nasuwają się jedynie w związku z kilkoma, być może nie najistotniejszymi kwestiami, ale trudno przejść nad nimi do porządku dziennego. Niejasne jest przyjęte w pracy kryterium normatywne, skoro mają je potwierdzać nienormatywne słowniki języka ogólnego, na przykład słownik „wileński” czy „warszawski”. Zamiar przedstawienia zapożyczeń wschodniosłowiańskich funkcjonujących w polszczyźnie, m.in. na przełomie XX i XXI wieku, każe zastanowić się, dlaczego zakres czasowy wspomnianych słowników kończy się na połowie wieku XX, czyli na słowniku pod red. W. Doroszewskiego (1958-69). 
Warto byłoby sięgnąć albo do słownika uniwersalnego pod red. S. Dubisza (2008), albo do praktycznego słownika współczesnej polszczyzny pod red. H. Zgółkowej (1994-2005). Ponadto zastanawia, przyczyna takiej oto kolejności słowników, że słownik obejmujący materiał staropolski jest wymieniany po słowniku polszczyzny XVI wieku (s. 14). Ani chronologia materiału, ani edycji obu dzieł nie uzasadniają tego rozwiązania. Pojawia się też wątpliwość, czy w odniesieniu do języka pisarzy, zwłaszcza związanych z kresami, należy mówić o materiale gwarowym? Sam status polszczyzny kresowej był nieraz dyskutowany i nie ma w tej materii jednolitego stanowiska językoznawców (por. m.in. Dejna 1984, Kurzowa 1985). Nie jest też jasne, jak ostatecznie rozumie autorka termin rutenizm, czy jako zapożyczenie ukraińskie czy białorusko-ukraińskie? (por. s. 30, 38).

Wprawdzie wykorzystane źródła dostarczyły bardzo obfitego materiału leksykalnego, ale m.in. moje doświadczenia dialektologiczne pokazują, że rzeczywiste zróżnicowanie fonetyczne wschodnich slawizmów funkcjonujących $w$ gwarowych i regionalnych odmianach polszczyzny jest jeszcze większe niż wynika to z niniejszego opracowania. Dowodzą tego m.in. nie występujące $\mathrm{w}$ opracowaniu $\mathrm{w}$ roli elementów haseł szeregowych postacie typu: bradziaga, chałuj, czartopałoch, czuryto, fanar, habal, horba, jełop, probój, skacina.

Przy omawianiu dorobku językoznawstwa w zakresie badań nad językiem starowierców mieszkających w Polsce dotkliwie daje się odczuć brak chociażby napomknięcia o Irenie Maryniakowej, wieloletnim współpracowniku Irydy Grek-Pabisowej i współautorce licznych opracowań, np. słownika tej gwary (1980).

Ogólnie opracowanie Anny Kosteckiej-Sadowej należy ocenić bardzo wysoko, wypełnia ono niewątpliwą lukę w literaturze, można rzecz, że było oczekiwane. Charakteryzuje je konsekwencja i zdyscyplinowanie metodologiczne. Zwraca uwagę powściągliwość, by nie powiedzieć ostrożność, w formułowaniu wniosków szczegółowych, dotyczących zwłaszcza źródła zapożyczenia. Uderza bogata dokumentacja źródłowa i doskonała orientacja $\mathrm{w}$ przebogatej literaturze, $\mathrm{nb}$. obficie $\mathrm{w}$ pracy cytowanej. W związku ze swoim charakterem i zawartością merytoryczną monografia powinna znaleźć licznych odbiorców nie tylko w środowisku językoznawców, zwłaszcza slawistów, dialektologów, etno- i socjolingwistów, ale też historyków i przedstawicieli innych dyscyplin z zakresu nauk humanistycznych i społecznych. 


\section{LITERATURA (CYTOWANA I PRZYWOŁYWANA)}

Atlas gwar mazowieckich, 1971-1990.

Atlas gwar wschodniostowianskich Białostocczyzny, 1980-2012, Wrocław-Warszawa.

Bajerowa I., 1964, Kształtowanie się systemu polskiego języka literackiego w XVIII wieku, Wrocław.

Czyżewski F., 1986, Atlas gwar polskich i ukraińskich okolic Włodawy, Lublin.

Dejna K., 1984, W sprawie tzw. dialektów kresowych, „Język Polski”, LXIX, s. 51-57.

Doroszewski W., 1934, Język Teodora Tomasza Jeża (Zygmunta Miłkowskiego). Studium z dziejów języka polskiego, XIX wieku, Warszawa.

Doroszewski W. (red.), 1958-1969, Słownik języka polskiego, Warszawa.

Dubisz S., (red.), 2008, Uniwersalny słownik języka polskiego, Warszawa.

Górnowicz H., 1967, 1973-74, Dialekt malborski, t. I: Fonetyka, fleksja, składnia, t. 2: Stownik, Gdańsk.

Grek-Pabisowa I., Maryniakowa I., 1980, Stownik gwary starowierców mieszkających $w$ Polsce, Warszawa.

Hrabec S., 1949, Elementy kresowe w języku niektórych pisarzy polskich XVI i XVII w., Torun.

Karaś H., 2011, Polska leksykografia gwarowa, Warszawa.

Klemensiewicz Z., 1974, Historia języka polskiego, Warszawa.

Kość J., 1999, Polszczyzna południowokresowa na polsko-ukraińskim pograniczu językowym, w perspektywie historycznej, Lublin.

Koneczna-Świderska H., 1929, Dialekt Księstwa Łowickiego, Warszawa.

Kuraszkiewicz W., 1932, Przegląd gwar województwa lubelskiego, Lublin.

Kurzowa Z., 1993, Język polski Wileńszczyzny i kresów pótnocno-wschodnich XV-XX w., Warszawa-Kraków.

Kurzowa Z., 1985, O polskich dialektach kresowych, "Język Polski", XV, s. 99-108.

Kurzowa Z., 1983, Polszczyzna Lwowa i kresów południowo-wschodnich do 1939 r., Warszawa-Kraków.

Nitsch K., 1913, O wzajemnym stosunku gwar ludowych i jezzyka literackiego, I: Pochodzenie polskiego języka literackiego, II: Wpływ prowincji ruskich na polszczyzne literacka, "Język Polski” 1, s. 79-83.

Nowowiejski B., 2009 (red.), Dziewiętnastowieczne słowniczki gwarowe z Polski pótnocno-wschodniej, Białystok.

Nowowiejski B., 2014, O słowniczku wyrazów ludowych Antoniego Wagi , „Białostockie Archiwum Językowe" 14, s. 81-98

Obrębska-Jabłońska A., 1972, Teksty gwarowe z Białostocczyzny z komentarzem językowym, Warszawa.

Pelcowa H., 1997, Słownictwo wschodniosłowiańskie w gwarach Polski środkowo-wschodniej w świetle związków językowych polsko-ukraińskich, [w:] Ze studiów nad gwarami wschodniosłowiańskimi w Polsce, red. F. Czyżewski, M. Łesiów, Lublin, s. 189-211. 
Pelcowa H., 2001, Polsko-białorusko-ukrainskie paralele leksykalne w świetle kulturowego dziedzictwa prasłowiańskiego, [w:] Język i kultura białoruska w kontakcie z sąsiadami, red. E. Smułkowa, A. Engelking, Warszawa, s. 141-151.

Praktyczny słownik współczesnej polszczyzny, 1994-2005, red. H. Zgółkowa, Poznań.

Smułkowa E., 1984, Uwagi do metody badań nad leksyka gwarowa pogranicza językowego, [w:] Studia nad gwarami Białostocczyzny. Morfologia i słownictwo, red. E. Smułkowa, I. Maryniakowa, Warszawa, s. 67-73.

Smolińska B., 1983, Polszczyzna pótnocnokresowa z przełomu XVII i XVIII wieku, Wrocław.

Sokólska U., 1999, Siedemnastowieczna polszczyzna kresów północno-wschodnich. Słowotwórstwo, słownictwo, frazeologia, Białystok.

Steffen W., 1984, Słownik warmiński, Wrocław.

Tokarski R, 1975, Zapożyczenia leksykalne a zmiany znaczenia w polu wyrazowym, "Język Polski", IV, s. 275-282.

Trypućko J., 1955, 1957, Język Władysława Syrokomli (Ludwika Kondratowicza). Przyczynek do dziejów języka literackiego w wieku XIX, cz. I-II, Uppsala.

Walczak B., 1980, O rozwoju znaczeniowym zapożyczeń leksykalnych, [w:] Język. Teoria - Dydaktyka. Materiały IV konferencji młodych językoznawców dydaktyków, Kielce, s. 159-187.

Woźniak K., 2000, Stan polskiej leksykografii gwarowej pod koniec XX wieku, [w:] Stowiańskie słowniki gwarowe, red. H. Popowska-Taborska, Warszawa, s. 17-51.

Zaleski J., 1969, 1975, Język Aleksandra Fredry, cz. I: Fonetyka, cz. II: Fleksja, składnia słowotwórstwo, słownictwo, Wrocław.

Zdancewicz T., 1964, Wpływy litewskie $i$ wschodniosłowiańskie w gwarach polskich pod Sejnami, „Acta Baltico-Slavica” I, s. 227-246.

Zdancewicz T., 1966, Wpływy białoruskie w polskich gwarach pod Sejnami, Poznań.

Zgółkowa H., 1994-2005, Praktyczny słownik współczesnej polszczyzny, Poznań.

Bogusław Nowowiejski

Uniwersytet w Białymstoku 